\title{
Access to Political Rights in Switzerland: Critique of the Naturalisation Process as a Source of Exclusion
}

In this article, we analyse and discuss the legal criteria granting access to facilitated naturalisation in Switzerland. Among the possible legal criteria, marriage to a Swiss citizen as a criterion for obtaining citizenship is emblematic of the conservative political background in this country. It is also influenced by gendered stereotypes within the law itself and its application. We argue in favour of a critical approach to the law in order to avoid the erasure of categories of individuals who are relegated to society's margins. In a healthy democracy and judicial system, the law ought to be designed so as to avoid reproducing exclusionary bias. In this regard, we also discuss why acceding to citizenship is a prerequisite for exercising one's political rights and thus, achieving inclusion in Switzerland.

\section{Introduction}

II. Questioning the Abstract Universalism of Democracy

III. Nationality as a Criterion for Exclusion from Citizenship

\section{Citation:}

VÉRONIQUE BOILLET / CLÉMENCE DEMAY, Access to Political Rights in Switzerland: Critique of the Naturalisation Process as a Source of Exclusion, sui generis 2021, p. 229

Prof. Dr. iur. Véronique Boillet, Associate Professor at the University of Lausanne, Center for Public Law (veronique.boillet@unil.ch). MLaw Clémence Demay graduate assistant, University of Lausanne, Center for Public Law (clemence.demay@unil.ch). This is the English version of the text "En marge des droits politiques - Une analyse des conditions d'inclusion dans le corps électoral suisse à l'aune de la pensée féministe" that will be published in: Cottier/Hotz/Kapferer (eds.), Recht in Bewegung - Droit en mouvement, Dike, forthcoming. URL: sui-generis.ch/186

DOI: https://doi.org/10.21257/sg.186

This work is licensed under a Creative Commons Attribution-Share Alike 4.0 International License. 


\section{Introduction}

1 It is well established that while the law is a tool of emancipation, it is also a tool to maintain conservatism and even oppression. ${ }^{1}$ The objective of this contribution is to propose a critical analysis of the conditions of access to Swiss citizenship. In particular, the goal is to identify the extent to which our legal system is likely to create marginalisation when it excludes individuals who refuse or who are simply unable to comply with the process of "assimilation" that the law requires of them. ${ }^{2}$

2 While the categories of law appear to be merely a faithful reflection of empirically observable reality, they are in fact only the result of a decision by the legislator that has the power to attach legal consequences to states of fact. ${ }^{3}$ The function of law is therefore never purely recognitive but always constitutive: law establishes what is acceptable or recommended at a time and within a defined society. ${ }^{4}$ And it is this choice, as it aims to define the notion of citizenship, that is the subject of our criticism. More specifically, we will deal with the notion of citizenship as a "legally codified status of belonging [...]"5, in other words, in the case of Switzerland, with the constitutional and legal conditions of belonging to the federal electorate and of exercising political rights.

3 With respect to Swiss political rights, we demonstrate the importance of feminist criticism of law, as its tendency to standardise is achieved through successive movements, the concepts being articulated in such a way that new marginalised groups are created at each stage. Indeed, in this field, the law uses apparently universal concepts that are in reality always deduced from or modelled on a

1 MARIE-XAVIER CATTO et al., Questions d'épistémologie: les études sur le genre en terrain juridique, in: Hennette-Vauchez/Möschel/ Roman (eds.), Ce que le genre fait au droit, Paris 2013, p. 4; FRANçoIs OST, A quoi sert le droit?, Bruxelles 2016, p. 80 f., the author describes the different uses of law, which vary according to the actors involved. In this regard, the law can be an instrument applied by an authority, a tool for leading an emancipatory struggle for victims of injustice, but also a weapon in the hands of the powerful and those who use the weapon to strengthen their interests.

2 A process that ignores the diversity of individuals who are governed by the law, as well as the existence of a power imbalance within a category itself. This aspect has been theorised by Monique Wittig, in particular to refer to the rejection of the experience of lesbian women within the "woman" category. This tendency to "homogenise" the population and deny diversity is the subject of criticism in intersectional feminism. Cf. ALEXANDRE JAUNAIT / CHAUVIN SÉBASTIEN, Représenter l'intersection. Les théories de l'intersectionnalité à l'épreuve des sciences sociales, Revue française de science politique $62 / 2012$, p. $5 \mathrm{ff}$.

3 ELSA FONDIMARE, Le genre, un concept utile pour repenser le droit de la non-discrimnation, Revue des droits de l'homme 5/2014, p. $4 \mathrm{f}$.

4 DANIÈLE LOCHAK, Dualité de sexe et dualité de genre dans les normes juridiques, Lex Electronica 2010, p.15ff.

5 YVES DÉLOYE, La citoyenneté entre devoir et engagement politique, in: Beaud/Saint-Bonnet (eds.), La citoyenneté comme appartenance au corps politique, Paris 2020, p. 28. heterosexual male frame of reference, with the consequence that subjects who deviate from this hegemonic norm are rendered invisible. 6 The interconnection of these different unifying notions thus pushes the marginalised individuals a little further at each step.

As a preliminary step, it is necessary to revisit certain el- 4 ements of feminist criticism of the concept of democracy which already endorses an idea of gender roles, and to propose a critical approach that challenges the notion of abstract universalism - a position that is also present in theories of citizenship. In the light of these theoretical considerations, we will examine the criterion of nationality as an element of inclusion in the "people" as a member of the federal electorate ${ }^{7}$ and the incidental effects, including the creation of a caste-like system in which different categories of the population are rendered invisible. ${ }^{8}$

\section{Questioning the Abstract Universalism of Democracy}

Before demonstrating the homogenising aspect of the law 5 in the area of political rights, we highlight certain elements of the feminist critique of democracy. ${ }^{9}$ Indeed, as many authors have pointed out, the democratic framework is already underpinned by a gender logic ${ }^{10}$ and the female category constitutes one of its "margins". The historical example of the exclusion of women from "universal" suffrage is, in this respect, emblematic and particularly useful for our critique regarding the exclusion of other categories of subjects. ${ }^{11}$

6 MICHÈLE L.CARON, Variations sur le thème de l'invisibilisation, Canadian Journal of Women and the Law 7/1994, p. 274; СATTO et al. (n.1), p.19.

7 The title 4 of the Federal Constitution, which contains art. 136 on the composition of the federal electorate, refers to "People and Cantons", seen. 35 .

8 The questioning of the ownership of political rights within a legal order also implies a potential reversal of the existing hierarchy between nationals and non-nationals: see, e.g., BRIGITTE STUDER, La conquête d'un droit, Neuchâtel 2021, p.104ff.

9 CAROLINE BEER, Democracy and Gender Equality, Studies in Comparative International Development 44/2009, p. $212 \mathrm{ff}$. The author reviews the various existing works that connect gender and the study of democracy as a political regime. She points out that the inclusion of women among the citizens of such a regime is not sufficiently taken into account to evaluate its democratic character. She disapproves of this situation since the granting of political rights to women - as to other categories of the population - constitutes not only a source of better protection for them, but also reinforces the acceptability of the regime, p. 213 and $218 \mathrm{ff}$.

10 BARBARA HOLLAND-CUNZ, Demokratie - StaatbürgerInnenschaft Partizipation, in: Rosenberger/Sauer (eds.), Politikwissenschaft und Geschlecht, Vienna 2004, p. 132; BRIGITTE STUDER, Universal Suffrage and Direct Democracy - The Swiss Case 1848-1990, in: Fauré (ed.), Political and Historical Encyclopaedia of Women, New York 2003, p. 689.

11 RUTH RUBIO-MARÍN, The Achievement of Female Suffrage in Europe: On Women's Citizenship, International Journal of Constitutional Law 12/2014, p. 4 ff.; STUDER (n. 8), p. 9 ff. 
6 While we accept that democracy is a political system in which power is derived - directly or indirectly - from the people, ${ }^{12}$ we also note that these two notions have been shaped and influenced by gendered representations denounced by feminist political scientists. For example, in her work, British professor of political thought, CAROLE PATEMAN, has criticised the "sexual contract", which is the corollary of the idea of the democratic social pact concluded between equal and free men, and which has given substance to the definition of democracy. ${ }^{13}$ According to her, the concept of a democratic regime composed of equal and free subjects aims above all at an alliance between "brothers", between men, whose status as free subjects is in contrast to the dependence of female subjects. ${ }^{14}$ From a political theory standpoint, men are essentially the subjects and their freedom derives from the sexual division of labour that allows them to participate in public life, while women are viewed as political subjects through the prism of the family. ${ }^{15}$ Historically, the gendered distribution of roles assigning women to private spaces and men to the public sphere has therefore long been considered irrelevant for thinking about democracy and the constitution of its political spaces. ${ }^{16}$

7 However, the construction of the division between private and public spaces, which is at the heart of the concept

12 The concept of democracy itself is not unequivocal. There are many controversies and studies about the notion and the elements that allow for the defining of a political regime as such. In this contribution, we will limit ourselves to a legal approach to democracy (MARTINA CARONI, Herausforderung Demokratie, RDS 2013, p. $11 \mathrm{ff}$; Y YO HANGARTNER / ANDREAS KLEY, Die demokratischen Rechte in Bund und Kantonen der Schweizerischen Eidgenossenschaft, Zurich $2000, \$ 11)$, as well as to a gender critique of it. For a broader overview of different theories of democracy and their critiques, see in particular: ALEXANDRE GEFEN / SANDRA LAUGIER, Le pouvoir des liens faibles, Paris 2020 or DOMINIQUE BOURG, Inventer la démocratie du XXIe siècle, Paris 2017.

13 CAROLE PATEMAN, The Sexual Contract, Oxford 1988. She insists on the need to integrate a gender reading of political theory in order to build a just and inclusive political system: “[T]he story of political genesis needs to be told again from yet another perspective. The men who (are said to) make the original contract are white men, and their fraternal pact has three aspects; the social contract, the sexual contract and the slave contract [...]", p. 221.

14 PATEMAN (n.13), p. 49. BLANCA RODRIGUEZ RUIZ/RUTH RUBIOMARIN, Le genre de la représentation: démocratie, égalité et parité, in: Hennette-Vauchez/Möschel/Roman (eds.), Ce que le genre fait au droit, Paris 2013, p. 166.

15 RUIZ/RUBIO-MARÌN (n.14). Cf. also, on the gendered division of labour in Switzerland: MICHELLE COTTIER/JOHANNA MUHEIM, Travail de Care non rémunéré et égalité de genre en droit de la famille suisse. Une évaluation critique du nouveau droit de l'enfant, RSD 2019 I, p. 6.

16 HOLLAND-CUNZ (n.10), p.139. She echoes the words of Professor Sandra Harding, who describes women as being on the fringes of the political arena in an article entitled Rethinking Standpoint Epistemology: What is Strong Objectivity?, in: Fox Keller/Longino (eds.), Feminism \& Science, Oxford 1996. See also CARL F. STYCHIN, Governing Sexuality: The Changing Politics of Citizenship and Law Reform, London 2003, p. $8 \mathrm{f}$. of democracy, has repercussions on the participation and representation of women, even when they have similar political rights to men. ${ }^{17}$ Furthermore, the entire democratic political culture is infused with male representations according to feminist researchers. The founding myths of the social contract underpinning the legitimacy of the political system are based on male narratives (William Tell, Rütli oath [Rütlischwur]), 18 instituting solidarity and fraternity which barely takes into account the interests of female subjects. ${ }^{19}$ Moreover, the areas of political socialisation are also strongly influenced by male circles (student associations traditionally reserved for men, Masonic houses, armies, etc.). ${ }^{20}$ Consequently, the gender-specific experience of the subjects and the power relationships that mark these experiences are not taken into account. These elements are, in fact, subsumed under the presumably all-encompassing experiences of male subjects. ${ }^{21}$ This observation is synthesised by the concept of "abstract universalism" in the literature and

17 LiNe BlattmanN, Männerbund und Bundesstaat, in: Blattmann/ Meier (eds.), Männerbund und Bundesstaat, Zurich 1998, p. 21. See also MARIE-CÉCILE NAVES, La démocratie féministe, Réinventer le pouvoir, Paris 2020, p. 266, who denounces the role of essentialising theories claiming a complementarity of quality and capacity between the two sexes, in the construction of such a separation of spaces; RUBIO-MARÍN (n.11), p. 6 ff.

18 BLATTMANN (n. 17). In Switzerland the term "Confederation" is used. Its members are historically primarily male citizens who have joined together to protect the rest of the population from possible attacks. According to her, the notion of citizenship is constituted mainly in the practice of war. This is reflected in the place given to the army as an institution of socialization to citizenship in the Swiss system.

19 On the political culture revealing and promoting gender stereotypes, see: IRIS BLUM / MONIKA IMBODEN, Eingebunden - Ungebunden Nationale Inszenierungen und politische Aktionsformen von Frauen seit 1945, in: Blattmann/Meier (eds.), Männerbund und Bundesstaat, Zurich 1998, p. $8 \mathrm{ff}$.

20 BLATTMANN (n.17), p. 21; MANON TREMBLAY / THANH-HUYEN BALLMER-CAO / BÉRENGÈRE MARQUES-PEREIRA / MARIETTE SINEAU, Genre, citoyenneté et représentation 2007, p. 4. It should be recalled that the Federal Court has forced the University of Lausanne to continue to grant the Zofingen student association the status of a university association even though the latter does not admit women. According to our Supreme Court, the overall weighing of the interests is in favour of the freedom of association and equality of treatment, invoked by [Zofingen] to the detriment of the principle-legitimate and important in itself-of equality between women and men, which [the University] wishes to establish in practice and promote, Judgement of the Swiss Federal Supreme Court ATF 140 I 201, consid.6.7.4. See also the data concerning the political, administrative, and economic elites in Switzerland, still largely male, Data base on Swiss elites, or the recent debate on the Basel guilds, CÉLINE ZUND, A Bâle, les membres de guildes se conjugueront au féminin, Le Temps of 9 April 2021.

21 See, in particular, STUDER (n. 8), in this sense: "the history of women's suffrage is a history of power: that of men who declare their own category as universal and naturalize the socially constructed relationship between men and women. It is also a history of structural violence, by the denial of a right; symbolic, by the exclusion of a space [....]", p. 154 (own translation). 
is not new. ${ }^{22}$ It developed at the beginning of the 20 th century and led ethnologist HEINRICH SCHURTZ to use the term Männerbund to designate modern democratic States, and specifically Switzerland where the relevance of the term has continued over the centuries. ${ }^{23}$

Ultimately, both the historical exclusion of women from the exercise of political rights and the discrimination they still face are central issues for a democratic system..$^{24}$ This abstract universalism thus questions the real scope of formal equality. ${ }^{25}$ Unquestionably, there are still many areas in which the inclusion of women has not been achieved, as the consequences and pitfalls of abstract universalism have not been fully recognised. ${ }^{26}$ Female citizens therefore had to be 'incorporated' into a supposedly universal political system. Universality was therefore to be understood as synonymous with masculinity. ${ }^{27}$ However, this fiction of the universal representativeness of the Swiss democracy is still conceived in terms of exclusion rather than inclusion, not only because other categories of the population are excluded (minors, foreigners, persons who are incapable of discernment), ${ }^{28}$ but also because the factual conditions for participation of marginalised individuals are not taken into account. ${ }^{29}$

22 BERENGERE MARQUES-PEREIRA, Citoyenneté, in: Achin et al. (eds.), Dictionnaire genre et science politique, Paris 2013, p.90; NAVES (n. 17), p. 265 proposes instead to build an "inclusive universal" project that takes into account the experiences of other categories of the population.

23 HEINRICH SCHURTZ, Altersklassen und Männerbünde, Eine Darstellung der Grundformen der Gesellschaft, Berlin 1902. The sociologist, LUC BOLTANSKI, made a similar observation in 1966 and stated that " $[\mathrm{t}]$ here is a sense in which Swiss society as a whole is impregnated with masculine values”, quoted in STUDER (n. 8), p.141.

24 For an in-depth presentation of feminist theories of democracy (MOUFFE, FRASER, ELSTHAIN, PATEMAN, ...), see HOLLAND-CUNZ (n. 10), p.132; MARQUES-PEREIRA (n. 22), p. 95; BEER (n. 9).

25 See, for example, RUBIO-MARÍN's comparative study on the percentage of women in the lower houses of the States of the European Union, (n. 11), p. 30

26 STUDER (n. 8). Some authors have, nevertheless, tried to resist this criticism by arguing that women benefit from some form of indirect participation because of the influence that some wives have over their husbands: cf. BLATTMANN (n.17) who denounces these efforts. See also, TREMBLAY et al (n. 20), p. 8 and p.123.

27 CHRISTINE NADEAU, La critique féministe, in: Nadeau (ed.), Justice e démocratie, Montréal 2007, p.128; TREMBLAY et al. (n. 20), p. 2; CATTO et al. (n.1), p.9.

28 VÉRONIQUE BOILLET, Le corps électoral fédéral, in: Diggelmann et al. (eds.), Verfassungsrecht der Schweiz, Zurich 2020, p. 3, N11; DIMITRI KOCHENOV, Inter-Legality - Citizenship - Inter-Citizenship, in: Klabbers/Palombella (eds.), The Challenge of Inter-Legality, Cambridge 2019, p.134.

29 The Swiss Federal Supreme Court itself has acknowledged in its judgement ATF 123 I 152 (JdT 1999 I 282) that in order to achieve a real equality of opportunity between men and women, alternative measures to equality in the law must be implemented: appointment of women to the top of political lists, improvement of training opportunities, promotion of part-time work, easier reintegration into the labour market, increase in the number of childcare spaces, etc. (consid. 6). More broadly, the various limits of a solely participatory
Therefore, the demand for an increase in representation of women in politics and within the different spaces of power constitutes a means of resistance and struggle against this abstract universalism that de facto hinders equality. ${ }^{30}$

Moreover, men's democratic culture and the de facto 9 barriers it imposes on a whole section of the population have the effect of diminishing the depth and quality of the public debate, as well as of the political action that results from it. ${ }^{31}$ Thus, as long as the power relations that frame social interaction and decision-making spaces are not redefined to take all stakeholders into account, their democratic legitimacy and efficiency will be impacted. ${ }^{32}$ Indeed, the adopted norms will remain pre-formatted by the social experience of a very particular category of the population, unaware of its privileges and the relativity of its point of view. ${ }^{33}$ We will see that the same applies to other forms of exclusion.

\section{Nationality as a Criterion for Exclusion from Citizenship}

If we focus on the Swiss legal order in more detail, we 10 must recall that the democratic principle is both the legitimacy criterion of the Constitution and the primary value on which Swiss institutions are based.34 The

approach to democracy are summarised and critically discussed in LUC BLONDIAUX, La démocratie participative, sous conditions et malgré tout. Un plaidoyer paradoxal en faveur de l'innovation démocratique, Mouvements 50/2007, p.118.

30 On that topic, JANE MANSBRIDGE, Les Noirs doivent-ils être représentés par des Noirs et les femmes par des femmes? Un oui mesuré, Raisons politiques 2/2013, p. 53 ff. For a definition of formal equality: Judgement of the Swiss Federal Supreme Court ATF 123 I 152 (JdT 1999 I 292). See also, RUIZ/RUBIO-MARÌN (n.14). It should be noted that this objective appears to be in line with the aims set out at art. 5 of the Convention on the Elimination of All Forms of Discrimination against Women (CEDAW; CC [classified compilation] 0.180), cf. COTTIER/MUHEIM (n.15).

31 ELVITA ALVAREZ / LORENA PAIRNI, Engagement politique et genre: la part du sexe, NQF 3/2005, p.110. They point out that the gender division of labour as well as other forms of inequality (such as the lack of childcare solutions for example) existing in Switzerland shape deep-rooted barriers to women's political participation in Switzerland. See also NAVES (n.17), p. 267, which also makes explicit the challenges of eradicating sexual violence or gender bias in education in order to achieve equality in practice. She also notes that the COVID-19 crisis has exacerbated existing inequalities and revealed the marginalization of women in public aid policies that have mainly benefited men, p. 265 and 268. The paradox is that public policy that is explicitly useful to women is always also indirectly useful to men, although the opposite is not true.

32 RUIZ/RUBIO-MARIN (n.14), p. 158.

33 GABRIELE WILDE, Politik und Recht, in: Rosenberger/Sauer (eds.), Politikwissenschaft und Geschlecht, Vienne 2004, p. 217.

34 THIERRY TANQUEREL, Les fondements démocratiques de la Constitution, in: Thürer/Aubert/Müller (eds.), Verfassungsrecht, Zurich $2001, \S 18$. 
"people" 35 occupy the position of the supreme organ of the community and collectively represent a fundamental pillar of democracy. ${ }^{36}$ Article 136 of the Federal Constitution defines the "people", in the sense of the federal electorate, as Swiss men and women aged 18 and over who have not been banned from voting for reasons of mental illness or mental weakness.

Citizenship is, by definition, the key to inclusion in a democracy, since it allows the exercise of political rights and thus active participation in political life and in the development of law. ${ }^{37}$ When citizens exercise their political rights, they are making use of a fundamental right expressly enshrined in the Federal Constitution which allows them not only to elect and vote, but also to be elected whether to the Federal Parliament, the Federal Council, or to a position as a judge at the federal level. As AUER, MALINVERNI and HOTTELIER point out, "the definition of the electorate is the first stone of the democratic institutional edifice". ${ }^{38}$ However, as with the concept of democracy, the concepts of people and of citizenship have a "homogenising" tendency and are constructed on a logic of otherness. ${ }^{39}$ Indeed, Article 136 of the Federal Constitution excludes a significant part of the population: minors, those incapable of discernment, and foreign nationals. It is on this last category that we will focus our analysis. ${ }^{40}$

35 Art. 136 of the Federal Constitution of 18 April 1999 is the first provision of Title 4 of the Constitution entitled "The People and the Cantons" (FC; RS 101). As STUDER (n. 8), describes "citizenship is what defines the individual right to belong to a community of autonomous actors while granting a person the freedom to be an autonomous, independent, self-determined actor. Citizenship is one of the main, if not the main, structuring category of modern democracies. It is central to the constitution of the state and modern society. It is the citizens who form 'the people' or the sovereign as the electorate is commonly called in Switzerland. They are the sovereigns, who hold the power and delegate it. It is around this category that democracy emerges, legitimises and stabilises itself." (own translation), p.12. On the concept of "the people", see also RENE A. RHINOW / MARKUS SCHEFER / PETER UBERSAX, Schweizerisches Verfassungsrecht, $3^{\text {rd }}$ ed., Basel 2016, N252 ff.

36 ANDREAS AUER/GIORGIO MALINVERNI/ MICHEL HOTTELIER, Droit constitutionnel suisse, $3^{\text {rd }}$ ed., Bern 2013, $\$ 618$.

37 HOLLAND-CUNZ (n. 10), p. 133.

38 AUER/MALINVERNI/HOTTELIER (n. 36), N623

39 See STUDER (n. 8), p. 9, who points out that many categories of people were excluded from political rights as early as the first Constitution of 1848. See also HOLLAND-CUNZ (n.10), p.135; BLATTMANN (n. 17), p. 26; NICOLAS BAMFORTH, Sexuality and citizenship in contemporary constitutional argument, International Journal of Constitutional Law 2/2012, p. 482; STYCHIN (n. 16), p. 8 ff.

40 Today, this category represents about a quarter of the population residing in Switzerland: see Federal Statistical Office (FSO), Permanent foreign resident population by citizenship, on 31 December 2019. AUER also points out that illegal immigrants are not included in these figures: ANDREAS AUER, Gedankenfetzen zur Figur des Staatsbürgers, in: Ehrenzeller et al. (eds.), Vom Staatsbürger zum Weltbürger ein republikanischer Diskurs in weltbürgerlicher Absicht, Zurich et al. 2001, p. 57. For the other two categories, see BOILLET (n. 28), N17 and N 35 ff.
The notion of people in accordance with the Constitution 12 excludes all persons who do not have Swiss nationality. This is a classic, ${ }^{41}$ but questionable, approach shared by many legal systems, according to which only citizens would share a sufficiently strong sense of loyalty towards their State to participate in decision-making (Bürgerdemokratie). ${ }^{42}$ From a conceptual point of view, access to nationality is based on the construction of an alterity relationship among the members of a population that is supposed to be homogeneous. ${ }^{43}$ The term citizenship therefore implicitly contains an aspect of prioritisation and standardisation. One part of the population will have access to norms and participate in their development, while the other part of the population will be those to whom these norms are addressed. This situation is questionable in the light of the principle of democracy enshrined in the Federal Constitution. ${ }^{44}$

Belonging to the category of "the people" also has anoth- 13 er political interest that makes it a major issue and was theorised by the philosopher Hannah Arendt through the idea of the "right to rights". ${ }^{45}$ According to Arendt, in order to benefit from the protection of the law and to participate in a legal system, it is necessary to be recognised as subjects under the law. Thus, a fundamental right that would be a prerequisite for all the others would be the "right to have rights", which implies that one is recognised as belonging to a given legal order and therefore a holder of the entire catalogue of other fundamental rights. Although the majority of fundamental rights are

\section{DÉLOYE (n. 5), p.28ff.}

42 BOILLET (n. 28), N24. "In this respect, the term 'stato-national' citizenship is used to reflect the idea that there is a 'cultural and moral homogeneity [among the citizens of a state] that is favourable to the promotion of an identity capable of absorbing particularities and limiting conflicts arising from a sense of belonging [to other cultures]'”, (own translation) YvES DÉLOYE, Sociologie historique du politique, Paris 2017, p. 65. This observation is, however, increasingly questionable in view of the importance that multinationality tends to take on, without translating into a disengagement toward one or another of the states of which a person is a national. See JOACHIM BLATTER/MARTINA SOCHIN D'ELIA/MICHAEL BUESS, Bürgerschaft und Demokratie in Zeiten transnationaler Migration: Hintergründe, Chancen und Risiken der Doppelbürgerschaft, study commissioned by the Federal Commission for Migration, Bern 2018, p. $57 \mathrm{ff}$.

43 STYCHIN (n.16), p. 7; GERARD DELANTY, Citizenship in a Global Age: Society, culture, politics, Buckingham 2000.

44 JEAN-FRANÇOIS AUBERT / PASCAL MAHON, in: Aubert/Mahon (eds.), Petit commentaire de la Constitution fédérale de la Confédération suisse du 18 avril 1999, Zurich et al. 2003, art.136 N3; CARONI (n. 12) at p. 47 ff.; TARKAN GÖKSU / PIERRE SCYBOZ, Droits politiques des étrangers et des Suisses de l'étranger, FZR 2002 I, p. 20 ff.; JOACHIM K. BLATTER/SAMUEL D. SCHMID / ANDREA C. BLÄTTLER, Vom Demokratiedefizit europäischer Nationalstaaten, Elektorale Exklusivität im Vergleich, in: Glaser (ed.), Politische Rechte für Ausländerinnen und Ausländer?, Zurich 2017, p. 309; HANGARTNER/KLEY (n. 12), N29. Also BLATTER/ SOCHIN D'ELIA / BUESS (n. 42), p. 67.

45 HANNAH ARDENT, The Origins of Totalitarianism, $3^{\text {rd }}$ ed., New York 1968, p. $291 \mathrm{ff}$. 
nowadays recognised independently of nationality, ${ }^{46}$ the fact remains that political rights in Switzerland - as well as freedom of establishment and protection against deportation $^{47}$ - are linked to Swiss nationality, which is thus a vector of integration and increased protection. As Brigitte Studer reminds us, citizenship is composed of several overlapping (but not necessarily inclusive) elements: citizenship is, first of all, a legal norm of public law on which nationality is based; it then ensures a social status with the rights that derive from it, such as integration into social protection; finally, it grants access to political rights and practices. ${ }^{48}$ As long as some individuals have only marginal access to nationality, their protection and opportunities for participation are diminished, ${ }^{49}$ despite the existence of other participation rights such as the right to petition or freedom of association. The latter do not allow them to influence political decision-making in the same way as other political rights available to nationals (art. 34 of the Federal Constitution), especially as they are not binding for the authorities. Thus, in order to defend their own interests, non-nationals are limited to using indirect means of participation, making them dependent on the goodwill of Swiss citizens who may or may not take their interests into account, a situation not unlike that of women who are forced to persuade men to represent them. ${ }^{50}$ As with the inclusion of women, access to the legal status of citizenship is therefore a guarantee that the interests of this category of people will be better protected and taken into account. ${ }^{51}$

\section{Homogenisation and Exclusion: The Example of Facilitated Naturalisation}

14 In Switzerland, the notion of citizenship is strongly influenced by the right of blood or jus sanguinis (as opposed to

46 SIOBHÀN MULLALY, Gender equality, citizenship: status and the politics of belonging, in: Albertson Fineman (ed.), Transcending the Boundaries of Law, New York 2011, p. 193.

47 CÉLINE GUTZWILER, in: Martenet/Dubey (eds.), Commentaire romand de la Constitution, Basel 2021, art. 37 N 8 (cit. CR Cst.-GUTZWILER). This is true even in terms of access to social assistance, since the fact of having benefited from such assistance can be a reason for expulsion.

48 STUDER (n. 8), p. 12.

49 WILDE (n. 33), p. 222; HELEN IRVING, Citizenship and nationality, in Irving (ed.), Constitutions and Gender, Cambridge 2017, p. 387 and p. 404. Nevertheless, the lack of protection criticised by ARENDT (n. 45) can be somewhat tempered by the rise of international human rights instruments, cf. MULLALY (n. 46), p. 193.

50 Suffragettes had access to other means of political action than voting or election. However, these means did not allow them to decide for themselves or to act directly on issues affecting them, STUDER (n. 8), p.12 and p.104 ff.

51 MANSBRIDGE (n. 30), p. 55. the right of soil,jus soli):52 the granting of political rights is limited to Swiss nationals and Swiss nationality is acquired in the first place through the establishment of lineage (art.1 SCA). ${ }^{53}$ Only the naturalisation procedure is likely to enable foreign nationals to acquire Swiss nationality. This procedure therefore plays a fundamental role from a democratic point of view. By defining the conditions under which naturalisation takes place, the Nationality Act not only establishes the conditions for acquiring nationality, but also indirectly defines the conditions for acquiring political rights, i.e. the conditions for obtaining "a ticket" to enter the Swiss democratic process. ${ }^{54}$ We will see not only that the requirements defined by this law are characterised by their strong "homogenising" nature, but also that their application is influenced by a normative vision of the notion of marriage. 55 In this respect, it should be recalled that women's struggle for political rights overshadowed another issue that was already relevant to the question of nationality: the need for women to conserve their nationality in case of marriage to a foreigner. Indeed, as Helen Irving notes, even as political rights were finally being granted to women, the legislation of many States continued to make women's nationality dependent on that of their husbands. ${ }^{56}$ In Switzerland, it was not until the revision of the Nationality Act on 1 January 1992 that Swiss women no longer lost their nationality - and therefore their political rights - as a result of marrying a foreigner. ${ }^{57}$

The Nationality Act distinguishes between an ordinary 15 naturalisation procedure (art. 9 ff. SCA) and a facilitated naturalisation procedure (art. $20 \mathrm{ff}$. SCA). As its name suggests, facilitated naturalisation aims to offer certain foreign nationals Swiss nationality under facilitated circumstances, and thus indirectly the granting of political rights in a facilitated manner. Yet, facilitated naturalisation essentially targets heterosexual married couples: the legislator considers that through the matrimonial ties that unite him or her to a Swiss citizen, the foreign applicant is presumed to have become more familiar with the

52 ANNE KRISTOL/JANINE DAHINDEN, Becoming a Citizen through Marriage: How Gender, Ethnicity and Class Shape the Nation, Citizenship Studies 2019, p. 8; KOCHENOV (n. 28), p.136. The authors stress that this principle prevails in a majority of States. Nevertheless, the specific criteria for naturalisation then vary greatly from one State to another, which indicates that it is a matter of political choice that prevails when adopting one or another as legal criterion.

53 Federal Act on Swiss Citizenship of 20 June 2014 (SCA; CC 141).

54 See CR Cst.-GUTZWILER, art. 37 N12 ff; IRVING (n. 49), p. 395.

55 KRISTOL/DAHINDEN (n. 52); Also DIETRICH CHOFFAT / MARTA ROCA I ESCODA / HELEN MARTIN, À certifier conforme. Les couples binationaux face à la loi helvétique, Revue européenne des migrations internationales $36 / 2020$, p. $281 \mathrm{ff}$.

56 IRVING (n. 49), p. $387 \mathrm{ff}$.

57 BRIGITTE STUDER, Citizenship as Contingent National Belonging: Married Women and Foreigners in Twentieth-Century Switzerland, Gender \& History 13/2001 and the references cited. 
way of life in Switzerland, which is why he or she benefits from the more favourable conditions for access to Swiss nationality and indirectly to political rights. ${ }^{58}$

Same-sex couples who have entered into a registered partnership currently benefit from an intermediate, but nevertheless discriminatory situation: even if they enjoy the shorter deadlines applicable to heterosexual couples, they must go through the ordinary procedure, which is more burdensome, gives a wider margin of appreciation to the administration and its actors, and is not subject to the same judicial remedies (art. 83 letter b LTF59) as the simplified one.60

17 Knowing that the naturalisation procedure is a compulsory step for foreigners to obtain political rights and thus access to the right to vote and to be elected, the risk of creating social marginality becomes apparent very quickly: not only are foreign nationals excluded from these rights, but the procedure that allows them to acquire them is highly "heteronormalised": only married heterosexual foreign couples benefit from a facilitated procedure to the present day.

Ultimately, the requirements defined by the Nationality Act are discriminatory. As explained, the most obvious discrimination is directed at homosexual couples. In addition, there is also a difference in treatment for couples living together. These couples, whether heterosexual or homosexual, are indeed forced to legalise their relationship in order to be able to benefit from rights associated with the generalisation that matrimonial ties make the foreign applicant more familiar with the Swiss way of life. Yet we know for example that same sex couples sometimes decide to renounce the conclusion of a partnership not only because of the disadvantages that this union creates or codifies - for example in terms of adoption but also because of the categorising effect that it is likely to have, especially in the professional environment. ${ }^{61}$ Differences in treatment also target single individuals,

58 State Secretary for Migration (SEM), Manuel Nationalité pour les demandes dès le1.1.2018, Chapitre 4, Bern 2018, p. 4. Critique: KоснENOV (n. 28), p.145. For this author, the definition of the legal criteria for the acquisition of nationality is the result of a political choice that is too often presented as self-evident, whereas the assumption that the acquisition of nationality influences the learning of certain social or cultural values is only a fiction.

59 Not available in English (Loi sur le Tribunal federal of 17 June 2005 [LTF; CC 173.110]). This difference results from the jurisdictional division between the federal authorities that direct the facilitated naturalisation process, and the cantonal authorities that are mainly responsible for ordinary naturalisation, CR Cst.-GUTZWILER, art. 38 N6, N22ff. and N36ff. The cantons and municipalities may, in fact, require additional conditions for ordinary naturalisation, particularly with regard to the integration requirement.

60 Art. 10 SCA. See CR Cst.-GUTZWILER, art. 38 N 25.

61 IRENE GROHSMANN / CHRISTINA HAUSAMMANN / OLGA VINOGRADOVA, Institutionelle Verankerung von LGBTI-Themen in der Schweiz, Bern 2014, p. 17 . regardless of their sexual orientation. Because there is no matrimonial relationship likely to presume familiarity with the Swiss way of life, single persons must meet the much stricter conditions of ordinary naturalisation. Finally, this is also sometimes the case for transgender people who may have to undergo complex legal procedures to access marriage based on their sexual orientation. ${ }^{62}$ Indeed, while a transgender woman who is registered as male may marry a woman, she will have to change her civil status to female before she can marry a man.

In addition to these differences in treatment in the law, 19 there are also differences in treatment in the application of the law. As ANNE LAVANCHY points out, marriage serves as a social institution mobilising moral values in the service of a formalising civil administration. When it concerns a binational couple, marriage is subject to an evaluation process on the basis of gendered and racialised criteria. ${ }^{63}$ Under the guise of objective enforcement of the law, civil registrars rely on their personal feelings to identify fraudulent couples. ${ }^{64}$ Binational couples then become suspicious as soon as they deviate from the norm ${ }^{65}$ and do not conform to the "ideology of romantic love". 66 At a later stage, such a process is repeated before the administrative authorities. In their field research, Anne Kristol and Janine Dahinden demonstrate that the requirements enshrined in the Nationality Act are applied by the administrative authorities according to a normative vision of the conjugal relationship and on the basis of a "hierarchy of merit" to obtain Swiss nationality based on stereotypes linked in particular to gender. ${ }^{67}$ In judging the legitimacy of marriage, factors such as age difference, the presence of children, or sexual fidelity are taken into account. ${ }^{68}$ In addition, there is the requirement that the bi-national marriage must endure over time, otherwise there is a "presumption of fraudulent acquisition of facilitated naturalisation" 69 - and indirectly of citizenship.

62 Federal Office of Justice, Rapport explicatif relatif à l'avant-projet concernant la révision du Code civil Suisse (changement de sexe à l'état civil), 23 May 2018, p. 2; GROHSMANN/HAUSAMMANN/VINOGRADOVA (n. 61), p. 16.

63 ANNE LAVANCHY, L’amour aux services de l'état civil: régulations institutionnelles de l'intimité et fabrique de la ressemblance nationale suisse, Migrations Société 62/2013, p. 66.

64 LAVANCHY (n. 63), p.70.

65 Due to a difference in age or social class, for example, LAVANCHY (n. 63), p.73.

66 Ideology built on elements such as: the unwillingness of the couple to live under the same roof, the refusal to have children or the failure to present the origin of their meeting or their marriage in a romantic and idealistic fashion, MAITE MASKENS, L'amour et ses frontières: régulations étatiques et migrations de mariage (Belgique, France, Suisse et Italie), Migrations Société 6/2013, p. 53.

67 KRISTOL/DAHINDEN (n. 52), p.12f.

68 KRISTOL/DAHINDEN (n. 52), p. 7.

69 Cf. Judgement of the Swiss Federal Administrative Court C-2140/2015 of 23 March 2016 [French], consid. 6.2 and its analysis in: DIETRICH/ ROCA I ESCODA/MARTIN (n. 55). 
20 In the end, it can therefore be observed that the nationality criterion, which at first sight seems gender neutral, is conservative, highly heteronormative, and based on stereotypes. And such stereotypes are likely to be reflected in the representativeness and diversity of political institutions.

One solution would, therefore, be to rethink the naturalisation process on the basis of the criticism mentioned above. In our view, however, this would not be sufficient in view of the democratic principle which implies that decisions must be taken by the people who are subject to them. ${ }^{70}$ In order to favour a more inclusive approach, without, however, fundamentally questioning the very notion of a federal electorate ${ }^{71}$ - the nationality requirement would therefore have to be waived. ${ }^{72}$ In this regard, several proposals have been made. The most common is to include a certain type of foreign national in the electorate: holders of a residence permit. ${ }^{73}$ Such an approach is open to criticism insofar as the Foreign Nationals and Integration Act $^{74}$ uses the same type of criteria as the

70 Among others: CR Cst.-GUTZWILER, art.39 N27; BLATTER/SCHMID/ BLÄTTER (n. 45), p.309; CARONI (n.12), p. 47 ff.; GÖSKU/SCYBOZ (n. 45); HANGARTNER/KLEY (n.12), N 29.

71 We refer here to the scientific debates on a post-national model of citizenship, in particular BAUBÖCK's view that democratic inclusion requires three elements, namely the inclusion of affected interests in political decisions, the involvement in civil and social rights systems of those subject to the law, and the recognition of membership and rights to political participation in a democratic community. Yet "these three modes of inclusion should be governed by specific normative principles that apply differently to varying personal circumstances" (own translation): RAINER BAUBÖCK, Trois principes d'inclusion démocratique, in: Beaud/Saint-Bonnet (eds.), La citoyenneté comme appartenance au corps politique, Paris 2020, p. 43.

72 BOILLET (n. 28), N24; IRVING (n. 49), p. 403. They both come to the same conclusion and set inclusion as a priority to grant better protection of women.

73 Among others, see CARONI (n.12), p. 53.

74 Federal Act on Foreign Nationals and Integration of 16 December 2015 (FNIA; CC 142.2)
Nationality Act and is therefore just as heterogeneous and stereotypical. ${ }^{75}$ It would, therefore, seem more appropriate to use the objective criterion of duration of presence. Foreign nationals who have resided in Switzerland for a certain period of time would then be eligible for political rights. ${ }^{76}$

\section{Conclusion}

Feminist criticism has highlighted the limits of historical 22 concepts of citizenship and democracy and has revealed some of the underlying stereotypes. Based on this observation, a more inclusive approach that considers the social reality has been proposed.

From this theoretical standpoint, we take the view that 23 the definition of the notion of citizenship, within the meaning of the Swiss Constitution, does not withstand criticism: the requirement of nationality for access to political rights no longer seems appropriate and its relevance is called into question. Thus, the demand to open up the criteria for access to political rights and citizenship remains a political issue that is subject to resistance, despite the imperfections of the legal requirements highlighted in this contribution. ${ }^{77}$

75 For example, the law treats a female foreign national married to a Swiss male national - in that case, the woman is entitled to a residence permit after five years (art. 42 para. 3 FNIA) - differently from a female foreign national who lives in a concubinage with a Swiss national-in that case, the woman has no right to a residence permit and must respect the more restrictive conditions of art. 34 FNIA, cf. BOILLET (n. 28), N28.

76 For a proposal with arguments in this sense, BOILLET (n. 28), N 27; CR Cst.-GUTZWILER, art.39 N 27.

77 STYCHIN (n. 16); TREMBLAY et al. (n. 20), p. 97 and p. 124 